\title{
(- OPEN ACCESS \\ Mental health benefits of interactions with nature in children and teenagers: a systematic review
}

\author{
Suzanne Tillmann, ${ }^{1}$ Danielle Tobin, ${ }^{1}$ William Avison, ${ }^{2,3,4,5}$ Jason Gilliland ${ }^{1,3,4,5,6}$
}

- Additional material is published online only. To view please visit the journal online (http://dx.doi.org/10.1136/ jech-2018-210436)

'Department of Geography, Western University, London, Ontario, Canada

${ }^{2}$ Department of Sociology, Western University, London, Ontario, Canada ${ }^{3}$ Department of Epidemiology and Biostatistics, Western University, London, Ontario, Canada

${ }^{4}$ Children's Health Research Institute, Lawson Health Research Institute, London, Ontario, Canada

${ }^{5}$ Department of Paediatrics, Western University, London, Ontario, Canada

${ }^{6}$ School of Health Studies, Western University, London, Ontario, Canada

\section{Correspondence to}

Dr Jason Gilliland, Department of Geography, Western University, London, ON N6A 5K6, Canada; jgillila@uwo.ca

Received 4 January 2018 Revised 23 May 2018 Accepted 24 May 2018

Published Online First

27 June 2018
Check for updates

To cite: Tillmann $\mathrm{S}$, Tobin D, Avison W, et al. J Epidemiol Community Health 2018:72:958-966.

\section{ABSTRACT}

Background It is commonly believed that nature has positive impacts on children's health, including physical, mental and social dimensions. This review focuses on how accessibility to, exposure to and engagement with nature affects the mental health of children and teenagers.

Methods Ten academic databases were used to systematically search and identify primary research papers in English or French from 1990 to 1 March 2017. Papers were included for review based on their incorporation of nature, children and teenagers (0-18 years), quantitative results and focus on mental health. Results of the 35 papers included in the review, the majority focused on emotional well-being and attention deficit disorder/hyperactivity disorder. Other outcome measures included overall mental health, self-esteem, stress, resilience, depression and health-related quality of life. About half of all reported findings revealed statistically significant positive relationships between nature and mental health outcomes and almost half reported no statistical significance.

Conclusions Findings support the contention that nature positively influences mental health; however, in most cases, additional research with more rigorous study designs and objective measures of both nature and mental health outcomes are needed to confirm statistically significant relationships. Existing evidence is limited by the cross-sectional nature of most papers.

\section{INTRODUCTION}

Children's mental health includes their emotional, psychological and social well-being and affects how they reach developmental milestones, learn healthy social skills, develop sound family and peer relationships, develop a sense of identity and positive self-esteem and learn resilience and coping with stress. ${ }^{1-7}$ Mental health issues developed at a young age have the potential to persist into adulthood, continuing the burden on the individual, family, friends and the healthcare system. ${ }^{89}$ While studies commonly examine individual-level factors (eg, biological, socioeconomic) associated with children's mental health outcomes, researchers are increasingly recognising the importance of external influences on children's mental health, such as characteristics of their home, school and neighbourhood environments.

This systematic review considered various forms of children's and teenagers' interactions with nature. The evidence to support the connection between nature and children's mental health is extremely diverse, dispersed and difficult to interpret. Therefore, there is an overwhelming need to critically review and synthesise what evidence currently exists to make appropriate recommendations that can effectively support future research, policy and practice. Previous reviews on the relationship between natural environments and mental health have tended to lump in papers on children with papers on adults. ${ }^{10-14}$ Due to the particular objectives and/or inclusion/exclusion criteria of these previous reviews, many relevant (and newer) studies with important findings for children have been overlooked. Likewise, there have been excellent reviews focused on mental health issues among unique subpopulations of youth in specific environments (eg, indigenous youth, Arctic) that have limited generalisability. ${ }^{15}$ Other reviews that deal with the benefits of nature for children's health focus on a variety of other outcomes, such as physical health, rather than mental health. ${ }^{16-18}$ The specific objective of this review is to examine the evidence for all children and teenagers (birth to 18 years) to determine how interacting with different types of nature may benefit the mental health of children and teenagers.

\section{METHODS}

The systematic review began with a scoping review to determine appropriate search terms related to nature, mental health and children and teenagers. ${ }^{19}$ Search terms were identified by the authors and finalised by an advisory panel of subject experts (see table 1). We used 10 bibliographic databases: PubMed, Scopus, PsycINFO, Geobase, ProQuest, SPORTDiscus, Sociological Abstracts, Leisure and Tourism Database, Physical Education Index and EMBASE. Within each database, we screened all English and French papers published 1 January 1990 to 1 March 2017. This period represents approximately one generation in the literature.

\section{Review process}

The review process was divided into three major steps: title screening, abstract screening and document screening. Title screening involved reviewing the outputs from each database search and downloading all titles that appeared relevant into a citation manager (Mendeley V.1.17.10). Of the 227153 titles screened, 1731 documents were downloaded for further review. Abstracts of all 1731 were then screened and 253 documents were retained which appeared to meet inclusion criteria: Population included children and teenagers 18 years and under, Intervention incorporated an element of nature, Outcome variable included a component of 


\begin{tabular}{ll}
\hline Table 1 & Database search terms \\
\hline Population & $\begin{array}{l}\text { child* OR youth OR adolescen* OR teen* OR babies } \\
\text { OR infant* OR toddler* OR preschooler* }\end{array}$ \\
\hline Intervention & $\begin{array}{l}\text { natur* OR green* OR "green space" OR greenspace OR "natural } \\
\text { environment" OR "b lue space" OR "open space" OR tree* OR } \\
\text { outdoor* OR outside OR park* OR forest* OR wildlife* OR wilderness } \\
\text { OR wood* OR plant* OR garden* OR vegetation OR landscape OR } \\
\text { playground }\end{array}$ \\
$\begin{array}{ll}\text { Outcome } \\
\text { "mental health" OR stress OR well-being OR "psychological well- } \\
\text { being" OR emotion* OR coping OR anxiety OR anxious OR sleep } \\
\text { OR mood OR "mood disorder" OR ADD OR ADHD OR "attention } \\
\text { deficit disorder" OR autism OR depression OR schizo* OR tourettes } \\
\text { OR "obsessive compulsive disorder" OR bipolar OR "depressive } \\
\text { symptoms" OR "psychological distress" OR flourishing OR } \\
\text { languishing OR behaviour OR behaviorbehaviour OR resiliency OR } \\
\text { self-esteem OR self-confidence }\end{array}$ \\
\hline
\end{tabular}

mental health and Study design was quantitative. Finally, the full text of all 253 retained documents was critically assessed using the same inclusion/exclusion criteria as the abstract screening, leaving 35 papers to be included in the systematic review. Finally, reference lists of all 35 papers were inspected for additional relevant citations; however, this search found no new papers (see figure 1). The review protocol was registered with PROSPERO (CRD42016046085) and findings reported following PRISMA guidelines.

\section{Data extraction}

Relevant data from the 35 full-text articles were identified and compiled into a data extraction table. This information was used to create a summary of the key characteristics, outcome measurement tools and findings of each study. A meta-analysis was not possible due to the heterogeneity of the methods and principal summary measures reported in the papers.

\section{Assessing bias}

Article quality was assessed using study quality assessment tools developed by the National Heart, Lung, and Blood Institute (NHLBI) of the U.S. National Institutes of Health (NIH) Quality Assessment Tools. To assess risk of bias due to study design or implementation, reviewers used one of five NHLBI tools dependent on study design. Two reviewers separately rated each study on a range of items in each tool and then considered the potential flaws (ie, item responses of 'no', 'cannot determine' and 'not reported') to create a scale then used to judge each study and assign an overall ranking of 'good', 'fair' or 'poor' quality. Whenever there was a disagreement between two reviewers, a third reviewer completed the rating and the majority rating was taken. In general, a 'good' study has a low risk of bias and results are deemed to be valid, whereas a 'fair' study has weaknesses making it susceptible to some bias deemed not sufficient to invalidate its results. A 'poor' rating indicates significant risk of bias, meaning results should be interpreted with caution or excluded from the body of evidence.

\section{RESULTS}

Of the 35 papers meeting eligibility criteria, 11 were conducted in the USA, 8 in the UK, 2 in Canada and the remaining 14 in other countries. All papers focused on children and teens ranging from 9 months to 18 years of age, with early adolescence being the most commonly studied age group (see table 2 ).

All of the outcomes studied in the 35 papers were assigned to 1 of 8 categories: emotional well-being (15 papers), attention deficit disorder/hyperactivity disorder (ADD/ADHD) $(10$
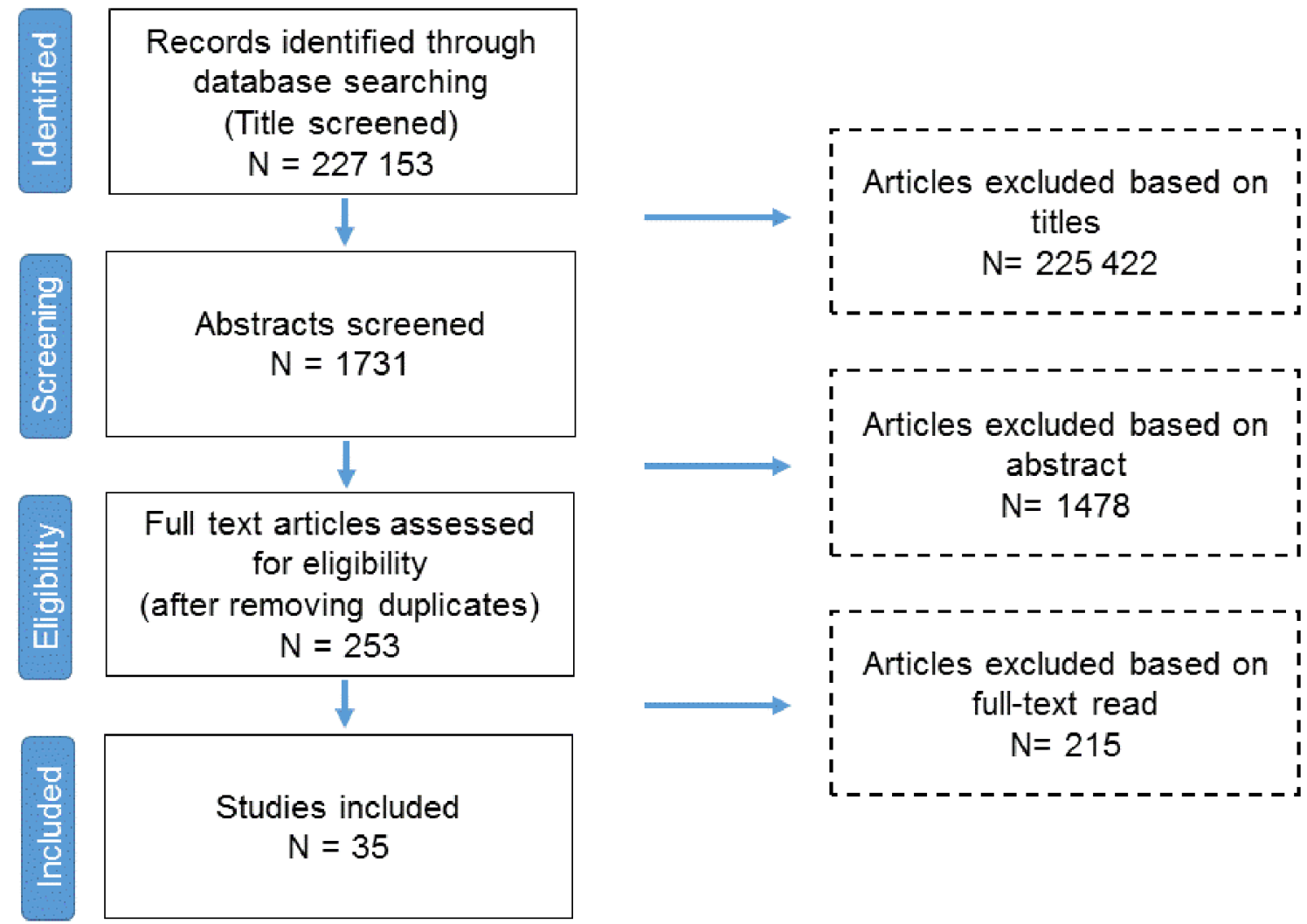
Table 2 Study characteristics and quality assessment of papers considering nature and mental health of children and teenagers

\begin{tabular}{|c|c|c|c|c|c|c|}
\hline $\begin{array}{l}\text { Ref\# } \\
\text { Country }\end{array}$ & $\begin{array}{l}\text { Ages } \\
\text { (years) }\end{array}$ & $\mathrm{N}$ & Element(s) of nature & $\begin{array}{l}\text { Nature } \\
\text { interaction(s) }\end{array}$ & Outcome(s) & $\begin{array}{l}\text { Study design } \\
\text { (quality) }\end{array}$ \\
\hline $\begin{array}{l}25 \\
\text { Spain }\end{array}$ & $7-10$ & 2111 & $\begin{array}{l}\text { Green Space } \\
\text { Blue Space } \\
\text { Greenness }\end{array}$ & $\begin{array}{l}\text { Accessibility } \\
\text { Exposure }\end{array}$ & $\begin{array}{l}\text { Emotional WB } \\
\text { Hyperactivity } \\
\text { Inattention } \\
\text { Mental Health }\end{array}$ & $\begin{array}{l}\text { Cross-sectional* } \\
\text { NC }(G)\end{array}$ \\
\hline $\begin{array}{l}20 \\
\text { Lithuania }\end{array}$ & $4-6$ & 1468 & $\begin{array}{l}\text { City Parks } \\
\text { Greenness }\end{array}$ & Accessibility & $\begin{array}{l}\text { Emotional WB } \\
\text { Hyperactivity } \\
\text { Mental Health }\end{array}$ & $\begin{array}{l}\text { Cross-sectional* } \\
\text { NC (F) }\end{array}$ \\
\hline $\begin{array}{l}26 \\
\text { England }\end{array}$ & $8-9$ & 52 & $\begin{array}{l}\text { Nature } \\
\text { Orienteering }\end{array}$ & Engagement & Self-esteem & $\begin{array}{l}\text { Intervention* } \\
\mathrm{NC}(\mathrm{F})\end{array}$ \\
\hline $\begin{array}{l}27 \\
\text { Australia }\end{array}$ & $13-16$ & 53 & $\begin{array}{l}\text { Outdoor } \\
\text { Adventure }\end{array}$ & Engagement & Mental Health & $\begin{array}{l}\text { Intervention* } \\
\mathrm{NC}(\mathrm{P})\end{array}$ \\
\hline $\begin{array}{l}28 \\
\text { Australia }\end{array}$ & $12-18$ & 36 & $\begin{array}{l}\text { Wilderness } \\
\text { Therapy }\end{array}$ & Engagement & $\begin{array}{l}\text { Emotional WB } \\
\text { Mental Health } \\
\text { Self-esteem } \\
\text { Depression } \\
\text { Resilience }\end{array}$ & $\begin{array}{l}\text { Intervention* } \\
\text { NC (F) }\end{array}$ \\
\hline $\begin{array}{l}29 \\
\text { U.S. }\end{array}$ & $12-18+$ & 50 & Horticulture Programme & Engagement & Self-esteem & $\begin{array}{l}\text { Intervention } \neq \\
C(F)\end{array}$ \\
\hline $\begin{array}{l}30 \\
\text { USA }\end{array}$ & $13-18$ & 100 & $\begin{array}{l}\text { Wilderness } \\
\text { Therapy }\end{array}$ & Engagement & Mental Health & $\begin{array}{l}\text { Quasi Empirical* } \\
\text { NC (G) }\end{array}$ \\
\hline $\begin{array}{l}31 \\
\text { USA }\end{array}$ & $12-15$ & 68 & Parks & Accessibility & Stress & $\begin{array}{l}\text { Cross-sectional* } \\
\text { NC (F) }\end{array}$ \\
\hline $\begin{array}{l}32 \\
\text { England }\end{array}$ & $\begin{array}{l}0.75,3 \\
5,7\end{array}$ & 6348 & Green Space & $\begin{array}{l}\text { Accessibility } \\
\text { Exposure }\end{array}$ & $\begin{array}{l}\text { Emotional WB } \\
\text { Hyperactivity Inattention }\end{array}$ & $\begin{array}{l}\text { Cross-sectionalł } \\
\text { NC (F) }\end{array}$ \\
\hline $\begin{array}{l}33 \\
\text { UK }\end{array}$ & $16-18$ & 120 & Outdoors & Exposure & $\begin{array}{l}\text { Emotional WB } \\
\text { Attention }\end{array}$ & $\begin{array}{l}\text { Intervention } \neq \\
\mathrm{NC}(\mathrm{P})\end{array}$ \\
\hline $\begin{array}{l}34 \\
\text { Netherlands }\end{array}$ & $12-15$ & 401 & Greenery & Exposure & Depression & $\begin{array}{l}\text { Longitudinal* } \\
\text { NC (F) }\end{array}$ \\
\hline $\begin{array}{l}35 \\
\text { USA }\end{array}$ & $13-18$ & 221 & $\begin{array}{l}\text { Wilderness } \\
\text { Therapy }\end{array}$ & Engagement & $\begin{array}{l}\text { Emotional WB } \\
\text { Mental Health }\end{array}$ & $\begin{array}{l}\text { Longitudinal } \\
\text { Case Study* } \\
\text { NC (F) }\end{array}$ \\
\hline $\begin{array}{l}36 \\
\text { UK }\end{array}$ & $12-15$ & 25 & Woodland Education & Engagement & Self-esteem & $\begin{array}{l}\text { Exploratory* } \\
\text { NC (F) }\end{array}$ \\
\hline $\begin{array}{l}37 \\
\text { Canada }\end{array}$ & $11-16$ & 17249 & $\begin{array}{l}\text { Natural Space } \\
\text { Green Space } \\
\text { Blue Space }\end{array}$ & Accessibility & Emotional WB & $\begin{array}{l}\text { Cross-sectional* } \\
\text { NC (F) }\end{array}$ \\
\hline $\begin{array}{l}38 \\
\text { Austria }\end{array}$ & $13-15$ & 133 & Schoolyard & Exposure & Emotional WB & $\begin{array}{l}\text { Pre-Post, Quasi- } \\
\text { Experimental* }^{*} \\
\text { C (F) }\end{array}$ \\
\hline $\begin{array}{l}39 \\
\text { USA }\end{array}$ & $9-11$ & 92 & $\begin{array}{l}\text { Natural } \\
\text { Environments }\end{array}$ & Accessibility & HRQOL & $\begin{array}{l}\text { Cross-sectionalł } \\
\text { NC (F) }\end{array}$ \\
\hline $\begin{array}{l}40 \\
\text { USA }\end{array}$ & $5-18$ & 452 & Green Outdoor & Exposure & ADHD & $\begin{array}{l}\text { Cross-sectionalł } \\
\text { NC }(P)\end{array}$ \\
\hline $\begin{array}{l}41 \\
\text { Germany }\end{array}$ & $9.4-11.7$ & 1932 & Green Space & Accessibility & $\begin{array}{l}\text { Emotional WB } \\
\text { Hyperactivity } \\
\text { Inattention }\end{array}$ & $\begin{array}{l}\text { Cross-sectional* } \\
\text { NC (F) }\end{array}$ \\
\hline $\begin{array}{l}42 \\
\text { Scotland }\end{array}$ & $8-11$ & 276 & Green Space & $\begin{array}{l}\text { Accessibility } \\
\text { Exposure }\end{array}$ & $\begin{array}{l}\text { Emotional WB } \\
\text { Self-esteem } \\
\text { HRQOL }\end{array}$ & $\begin{array}{l}\text { Cross-sectional* } \\
\text { NC (G) }\end{array}$ \\
\hline $\begin{array}{l}43 \\
\text { Germany }\end{array}$ & 14 & 12 & $\begin{array}{l}\text { Outdoor } \\
\text { Adventure }\end{array}$ & Engagement & $\begin{array}{l}\text { Mental Health } \\
\text { Stress }\end{array}$ & $\begin{array}{l}\text { Intervention } \\
\text { Pilot Study* } \\
\text { NC (P) }\end{array}$ \\
\hline $\begin{array}{l}44 \\
\text { South } \\
\text { Africa }\end{array}$ & $\begin{array}{l}\text { Grade } \\
10\end{array}$ & $76 \S$ & $\begin{array}{l}\text { Outdoor } \\
\text { Adventure Education }\end{array}$ & Engagement & $\begin{array}{l}\text { Emotional WB } \\
\text { Stress }\end{array}$ & $\begin{array}{l}\text { Pre-Post } \\
\text { Experimental* } \\
\text { NC (G) }\end{array}$ \\
\hline $\begin{array}{l}6 \\
\text { UK }\end{array}$ & $11-12$ & 75 & Park & Exposure & Self-esteem & $\begin{array}{l}\text { Counterbalanced } \\
\text { Randomised Cross Over* } \\
\text { C (P) }\end{array}$ \\
\hline $\begin{array}{l}7 \\
\text { Canada }\end{array}$ & $12-18$ & 73 & $\begin{array}{l}\text { Outdoor Adventure } \\
\text { Leadership Experience }\end{array}$ & Engagement & $\begin{array}{l}\text { Mental Health } \\
\text { Self-esteem } \\
\text { Resilience }\end{array}$ & $\begin{array}{l}\text { Intervention } \neq \\
\mathrm{C}(\mathrm{G})\end{array}$ \\
\hline
\end{tabular}




\begin{tabular}{|c|c|c|c|c|c|c|}
\hline $\begin{array}{l}\text { Ref\# } \\
\text { Country }\end{array}$ & $\begin{array}{l}\text { Ages } \\
\text { (years) }\end{array}$ & $\mathrm{N}$ & Element(s) of nature & $\begin{array}{l}\text { Nature } \\
\text { interaction(s) }\end{array}$ & Outcome(s) & $\begin{array}{l}\text { Study design } \\
\text { (quality) }\end{array}$ \\
\hline $\begin{array}{l}45 \\
\text { UK }\end{array}$ & 11 & 18 & Forest Schools & Engagement & Emotional WB & $\begin{array}{l}\text { Intervention* } \\
\text { NC (F) }\end{array}$ \\
\hline $\begin{array}{l}46 \\
\text { Israel }\end{array}$ & $15-18$ & 94 & $\begin{array}{l}\text { Wilderness } \\
\text { Therapy }\end{array}$ & Engagement & Self-esteem & $\begin{array}{l}\text { Intervention* } \\
\text { C (F) }\end{array}$ \\
\hline $\begin{array}{l}47 \\
\text { Sweden }\end{array}$ & $3-5.9$ & 169 & $\begin{array}{l}\text { Outdoor Preschool } \\
\text { Environment }\end{array}$ & $\begin{array}{l}\text { Accessibility } \\
\text { Exposure }\end{array}$ & Emotional WB & $\begin{array}{l}\text { Cross-sectional }{ }^{*} \\
\text { NC (P) }\end{array}$ \\
\hline $\begin{array}{l}48 \\
\text { USA }\end{array}$ & $7-12$ & 17 & Park & Exposure & ADHD & $\begin{array}{l}\text { Single Blind } \\
\text { Control Trial* } \\
\text { C (G) }\end{array}$ \\
\hline $\begin{array}{l}49 \\
\text { USA }\end{array}$ & $5-18$ & 421 & $\begin{array}{l}\text { Grass } \\
\text { Trees }\end{array}$ & Exposure & ADD/ADHD & $\begin{array}{l}\text { Cross-sectionalf } \\
\text { NC (P) }\end{array}$ \\
\hline $\begin{array}{l}50 \\
\text { USA }\end{array}$ & $7-12$ & 96 & $\begin{array}{l}\text { Greenness Trees } \\
\text { Grass }\end{array}$ & $\begin{array}{l}\text { Accessibility } \\
\text { Exposure }\end{array}$ & ADD/ADHD & $\begin{array}{l}\text { Cross-sectionalf } \\
\text { NC (P) }\end{array}$ \\
\hline $\begin{array}{l}51 \\
\text { Netherlands }\end{array}$ & $9-17$ & 12 & Natural (Wooded) Setting & Engagement & $\begin{array}{l}\text { Emotional WB } \\
\text { ADHD }\end{array}$ & $\begin{array}{l}\text { Intervention‡ } \\
\text { NC (G) }\end{array}$ \\
\hline $\begin{array}{l}52 \\
\text { New } \\
\text { Zealand }\end{array}$ & $12-18$ & 8500 & Garden & Engagement & $\begin{array}{l}\text { Mental Health } \\
\text { Depression }\end{array}$ & $\begin{array}{l}\text { Cross-sectional } \\
\text { NC (F) }\end{array}$ \\
\hline $\begin{array}{l}53 \\
\text { New } \\
\text { Zealand }\end{array}$ & $11-14$ & 108 & Green Space & Exposure & Emotional WB & $\begin{array}{l}\text { Cross-sectionalł } \\
\text { NC (G) }\end{array}$ \\
\hline $\begin{array}{l}54 \\
\text { USA }\end{array}$ & $\begin{array}{l}\text { Grades } \\
3-5\end{array}$ & 337 & $\begin{array}{l}\text { Outdoor } \\
\text { Yard }\end{array}$ & Accessibility & Stress & $\begin{array}{l}\text { Cross-sectionalł } \\
\text { NC (F) }\end{array}$ \\
\hline $\begin{array}{l}21 \\
\text { USA }\end{array}$ & $10-15$ & 879 & $\begin{array}{l}\text { Outdoor } \\
\text { Adventure }\end{array}$ & Engagement & Resilience & $\begin{array}{l}\text { Intervention* } \\
\text { NC (G) }\end{array}$ \\
\hline $\begin{array}{l}55 \\
\text { UK }\end{array}$ & $8-9$ & 25 & School Field & Exposure & Self-esteem & $\begin{array}{l}\text { Counterbalanced } \\
\text { Randomised Cross-over* } \\
\text { NC (F) }\end{array}$ \\
\hline
\end{tabular}

* Study design originally mentioned in paper.

tSurvey used was designed for children ages 12-18, but participant age not specified.

‡Study design assigned by reviewer.

$\S$ Males only.

qFemales only.

Study Quality Assessment: (G), Good; (F), Fair; (P), Poor.

$A D D$, attention deficit disorder; ADHD, attention deficit hyperactivity disorder; HRQOL, health-related quality of life; , study design included control group; NC, no control group; WB, wellbeing.

papers), overall mental health (9 papers), self-esteem (9 papers), stress (4 papers), resilience (3 papers), depression (3 papers) and health-related quality of life (HRQOL) ( 2 papers). Online supplementary table 1 summarises the measurement tools used in each paper, whereas online supplementary table 2 sorts the 35 papers by outcome, with the eight outcomes appearing in order according to number of papers studying that outcome. As some papers examined more than one outcome, the total entries in online supplementary table 2 is more than 35 .

Within the 35 papers, there was substantial diversity with respect to the specific elements of nature under consideration. The elements under study included green space (six papers), water/'blue' space (two papers), greenness/greenery (four papers), vegetation (ie, grass, trees) (two papers), gardens (one paper), parks (four papers), outdoor programmes/education (eight papers), wilderness therapy (four papers), forest schools (one paper) and various outdoor/natural settings (ie, schoolyards, green outdoor settings) (nine papers).

There was also considerable variation among the methods researchers used to assess children's interaction with nature. Despite the heterogeneity, a closer examination of study methods allowed us to group each study into one of three broad categories we define as 'accessibility', 'exposure' and 'engagement' (see table 3 for results based on nature interaction). In simple terms, accessibility refers to the ease of reaching destinations. Accessibility influences the likelihood a child will encounter or interact with nature, but does not necessarily equate to direct contact or interaction. For example, in most studies reviewed here, accessibility measures are passive and opportunity-based and tend to be operationalised in terms of distance/proximity to one or more elements of nature or density/coverage of one or more nature elements within an area around home. On the other hand, exposure can be defined as the condition of being presented to view, having contact with or being subjected to some effect or influence. Exposure, therefore, implies that the child has a direct encounter with nature, rather than mere opportunity. Nevertheless, in most studies reviewed here, exposure is a measure of incidental contact and is operationalised in terms of 'time spent in/near' or simply 'use of', a natural area such as a park. Engagement refers to involvement or participation in an activity and differs from the other two categories in that it implies an interaction with nature which is more direct, intentional and sustained. For example, the most popular form of engagement described in the studies reviewed here was participation in a wilderness therapy programme for days/weeks.

As displayed in table 3 (and online supplementary table 2), the 35 papers reported a total of 100 individual findings on the relationship between children's and teenagers' mental health and 
Table 3 Findings by outcome, type of nature interaction and study quality

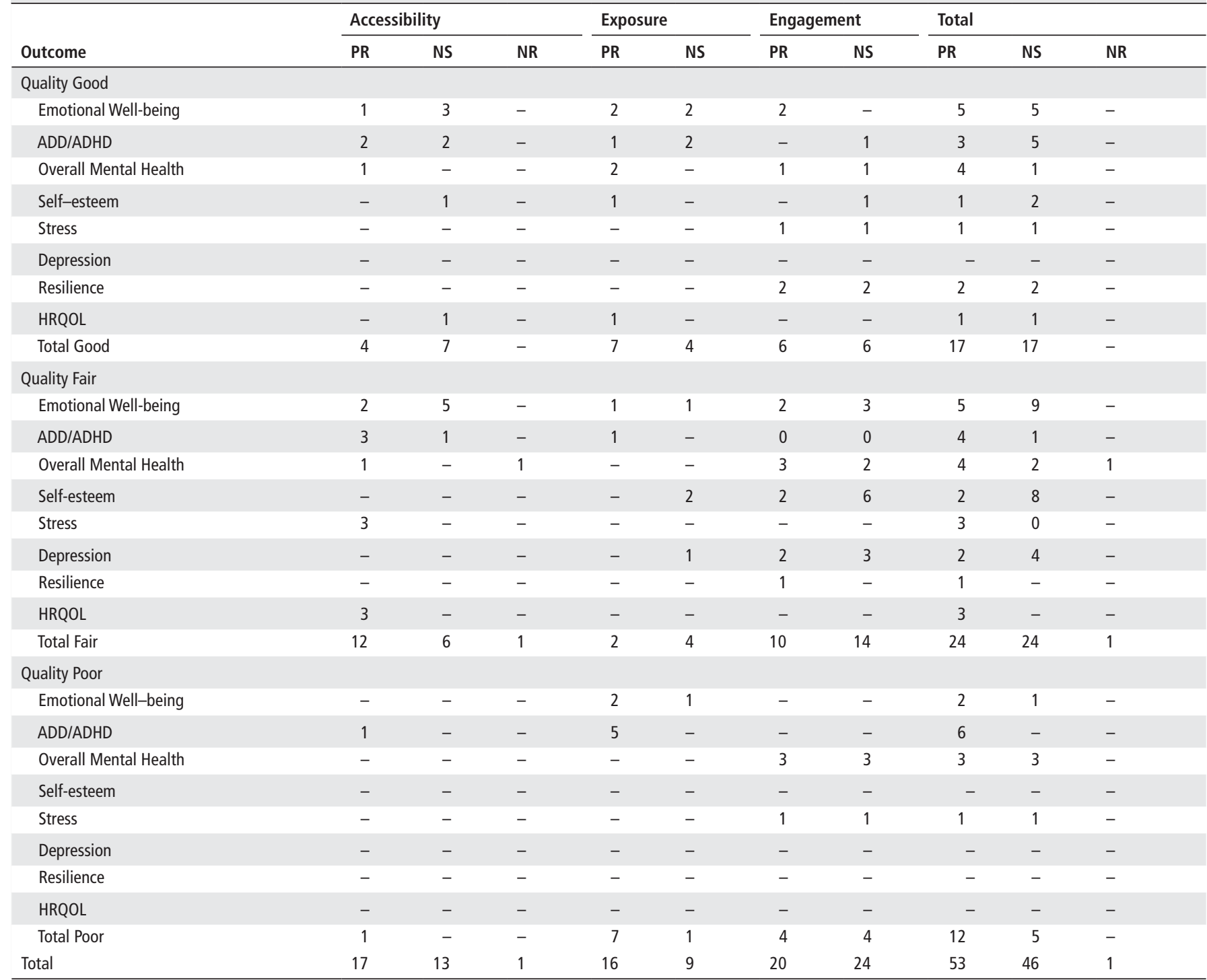

ADD, attention deficit disorder; ADHD, attention deficit hyperactivity disorder; HRQOL, health-related quality of life; NR, nature has significant negative impact on outcome; NS, nonsignificant finding; PR, nature has significant positive benefit on outcome.

nature. Over half of the findings (53 of 100) confirmed statistically significant positive relationships (ie, positive benefits of nature) (PR), whereas the remaining findings were non-significant (NS). Only one paper reported a single finding suggesting nature had negative effects on children's mental health (NR).

\section{Emotional well-being}

Fifteen papers included emotional well-being as a dependent variable. Emotional well-being was captured through variables such as emotional health, emotional symptoms, emotional intelligence, mood and emotional problems. Within the 15 papers, 12 findings demonstrated a significant positive relationship between nature and emotional well-being, whereas 15 findings were deemed non-significant. After removing two papers rated as poor quality, only 10 out of 23 findings identified a significant positive relationship between nature and emotional well-being.

\section{Attention deficit disorder/hyperactivity disorder (ADD/ADHD)}

Ten papers assessed nature interactions and ADD, ADHD or symptoms related to these two disorders (hyperactivity, inattention and attention). Within the 10 papers, there were a total of 19 findings, with 13 exhibiting statistically significant positive results. Nevertheless, six findings came from studies rated poor quality. After removing poor studies, seven out of 13 findings identified a statistically significant positive relationship. Increased accessibility to nature (6/9 significant positive findings) and increased exposure (7/9 significant positive findings) to nature were associated with improvements in $\mathrm{ADD} / \mathrm{ADHD}$ symptoms.

\section{Overall mental health}

Nine papers looked at an overall measure of children's mental health. Six papers focused on how engagement with nature, through wilderness and adventure programming, can affect overall mental health in teenage children. Overall mental health was assessed through several measures, for example psychological well-being, psychological distress or overall mental health. Eleven out of 18 findings within the 9 papers identified a significant positive relationship with nature. After removing poor findings, 8 out of 12 findings identified a significant positive relationship. One study found a negative association between residential surrounding greenness and overall mental health. ${ }^{20}$ 


\section{Self-esteem}

Compared with other outcomes, self-esteem exhibited the most non-significant findings compared with significant positive findings. Nine papers measured the relationship between self-esteem and nature, with most focusing on nature through engagement. Ten out of 13 findings supported a non-significant relationship; no studies were rated poor quality.

\section{Stress}

Accessibility and engagement to nature were both measured in relationship to stress in four papers. Five out of seven findings found interacting with nature to be significantly positively associated with reduced stress. After removing all poor findings, four out of five findings identified a significant positive relationship.

\section{Depression}

The majority of findings in the three papers focusing on depression were non-significant, with four of six findings showing no significant relationship with nature, and no studies were rated poor. All three studies measured depressive symptoms through various scales.

\section{Resilience}

All three studies measuring resilience used a form of outdoor programming, or engagement, to assess the relationship to nature. Resilience was subdivided into measures of sense of mastery, relatedness and emotional reactivity. It was found that adventure programmes resulted in an increase in mastery (improved self-efficacy and coping skills) and relatedness (more comfortable interacting with others) and decrease in emotional reactivity (ability to manage emotions when upset). ${ }^{21}$ Three out of five findings were found to show significant positive associations between resilience and nature, no studies were rated poor.

\section{Health-related quality of life (HRQOL)}

Two papers used HRQOL as a measure of mental health. Of the five findings taken from these papers, four showed a significant positive association with nature, no studies were rated poor. HRQOL takes into account factors influencing mental health including physical, emotional, social, school, family, friends and self-esteem functioning.

\section{Accessibility, exposure, engagement}

Engagement was the most commonly used interaction to measure the relationship between children's and teenagers' mental health and nature (15 papers); however, there were fewer positive significant findings than non-significant findings for this type of nature interaction $(20: 24)$. Fourteen papers measured nature through exposure and 11 through accessibility. The largest gap in the ratio between positive significant and non-significant findings was for exposure to nature (16:9), with accessibility falling between engagement and exposure (17:13).

\section{Geographic differences}

There are few geographical patterns among the findings; however, five out of the six studies set outside of North America and Europe dealt with children's and teenagers' engagement with nature, whereas the type of interactions studied in North America and Europe were more mixed among accessibility, exposure and engagement. Additionally, studies set in North America were more likely to report positive significant findings than non-significant findings (18:7), distinguishing them from studies in Europe (PR 23:NS 27:NR 1), Australia/New Zealand (PR 9: NS 8), Africa (PR 3: NS 1) and Asia (PR 0: NS 2).

\section{Risk of bias}

The quality assessment process revealed 9 good, 19 fair and 7 poor papers. The majority of the findings fell within the papers representing a fair quality assessment. After removing findings from papers rated as 'poor', the evidence base contained 41 positive significant findings (previously 52), 41 non-significant results (previously 45), and 1 negative significant finding. This decrease resulted in an equal significant positive results to non-significant results ratio, creating an inconclusive set of findings. Removing poor studies gives a more accurate picture of the relationship between nature and the mental health of children and teens. The majority of findings (12/17) that were removed came from studies researching the association between ADD/ ADHD or overall mental health and nature.

\section{DISCUSSION}

This review showed significant positive findings on the benefits of nature for all mental health outcomes; however, ADD/ ADHD, overall mental health, stress, resilience and HRQOL were the only outcomes that demonstrated more positive significant findings over non-significant findings. Several outcomes (emotional well-being, self-esteem, depression) were associated with a greater number of non-significant findings than positive significant findings, supporting the inconclusive nature of the evidence reported in previous reviews. ${ }^{11} 12$ Furthermore, among all studies only one finding reported a significant negative impact of greenness on a subgroup of children. ${ }^{20}$ Clearly additional research is needed, with more rigorous study designs, to confirm the benefits of nature interactions and mental health outcomes.

Framing the types of nature interactions in terms of 'accessibility', 'exposure' and 'engagement' highlighted the distribution of significant positive findings. Among exposure studies, the larger ratio between positive-significant and non-significant findings suggests this type of interaction is the most beneficial and may be the most effective approach for intervention strategies. Among accessibility studies, there was a smaller gap between positive-significant and non-significant findings, potentially due to the fact that accessibility to a particular environment does not equate to use of that environment. Among engagement studies, more findings were non-significant than positive-significant, indicating an inconclusive association between nature engagement and the mental health of children and teens; however, it is noteworthy that the majority of these studies focus on less healthy, 'at risk' populations participating in wilderness therapy or outdoor adventure programmes. Further investigation needs to examine how those programmes may benefit general healthy populations.

Studies of emotional well-being, although the most studied outcome, exhibited more non-significant findings than significant-positive findings (14:11). This calls for more rigorous investigations, as emotional well-being is critical for mental health. Findings clearly demonstrate the benefits of nature interaction for decreasing ADD/ADHD symptoms. This has important implications for teachers implementing strategies to help children focus in the classroom. The holistic measure of overall mental health was also most commonly assessed through engagement, finding an overall significant positive relationship; however, there was considerable variation among the tools used by researchers to assess overall mental health. A more universal measure of overall mental health applied to accessibility, exposure and engagement 
with nature could help to clarify this relationship. The majority of findings related to nature and self-esteem were non-significant; however, most of these studies focused on engagement, suggesting further research should investigate how other types of nature interactions may impact self-esteem. Findings indicate that interacting with nature can help reduce children's and teenagers' stress levels; however, these findings are based on a small number of studies and additional research could help confirm the benefits. Finally, for those outcomes with few findings (depression, resilience and HRQOL), it is difficult to interpret a relationship one way or the other. Therefore, more research needs to be conducted to build on potential findings discovered here. All of the findings here suggest that more universal tools should be used to measure both outcomes of mental health as well as nature interactions, in order to more confidently conclude a relationship between the mental health of children and teenagers and nature.

This review supports the application of these findings in various forms of policy, including municipal planning, public health and school board policies. The findings can support policymakers in designing future plans as well as strengthening current policies that take into consideration the importance of natural environments. Furthermore, school boards can use these findings to prioritise school outdoor spaces which are beneficial to the students and to the whole community. By prioritising investments of natural spaces at all levels of government as well as within school districts, children have a better chance of receiving the benefits of interacting with nature.

\section{Strengths and limitations}

This systematic review was comprehensive, searching 10 databases resulting in 227153 titles screened. ${ }^{19}$ Having multiple researchers assess abstracts and extract data added methodological rigour. Providing a quality assessment for each paper allows for a more accurate assessment of the weight of the evidence. Additionally, the review focused on children in general rather than a special subgroup of children, allowing the findings to be applicable to a wider population. Finally, conceptualising interactions with nature in terms of accessibility, exposure and engagement was a significant advancement over previous reviews and provides a deeper understanding as to what type, dose and duration of nature is required to influence change in the mental health of children and teenagers.

One limitation relates to the difficulty of scoring study quality. The subjective nature of observational studies does not allow for a clear 'yes' or 'no' answer to some questions designed for intervention based studies. Furthermore, papers based on qualitative methods were not included in this review due to the difficulties of comparing findings among studies. Their inclusion may have provided for a more fulsome understanding of the benefits of nature for the mental health of children and teenagers. We were unable to complete a meta-analysis with the 35 studies collected due to the heterogeneity of the measures used in each study. The majority of the studies had fairly small sample sizes and were from Europe, North America and other developed regions which can also limit the generalisability of the findings.

\section{Future directions}

This review calls for more longitudinal studies to assess the long-term effects that interactions with nature have on mental health, as changes in mental health outcomes cannot always be assessed over a short period. Longitudinal studies would support the assessment of the effects of different doses of nature and potential persistence of effects. The majority of the findings presented here illustrate that nature benefits children's and teenagers' mental health. Some contradictory findings, however, highlight the need for greater attention on how nature's effects differ between populations (ie, toddlers, adolescents). Furthermore, very few studies assessed childhood depression and no studies assessed anxiety, which have more recently come to the attention of public health professionals. Therefore, more research on nature's connection to these health issues is strongly encouraged. The majority of studies focusing on nature engagement target vulnerable or 'at risk' populations, limiting generalisability of findings; future studies should focus on healthy populations to inform change in policy and practice more generally. Likewise, more research is needed in regions outside North American and Europe, especially in less developed nations, to improve generalisability of findings. More rigorous tools are required for measuring nature, nature interactions and mental health outcomes. Indeed, more rigorous measures would allow researchers to more robustly identify associations and causal relationships and to better understand the potential pathways linking nature and positive outcomes for children's and teenagers' mental health. ${ }^{22-24}$

\section{CONCLUSION}

The primary purpose of this review was to compile and evaluate the existing evidence linking nature and the mental health of children and teenagers. The results demonstrate that interacting with nature is positively associated with the mental health of children and teenagers. The findings, although somewhat

\section{What is already known on this subject?}

- Nature has a significant impact on health. Previous reviews have identified the overall health effects of nature on a variety of health outcomes including physical, mental, social and cognitive health.

- These reviews have largely highlighted the impact of nature on adult populations, reporting positive effects as well as many inconclusive results.

- The current review helps to close gaps in the literature related to the impact of nature on children's and teenagers' mental health.

\section{What this study adds}

- This study critically examines current literature focusing on how nature influences children's and teenagers' mental health.

- It presents a framework for facilitating comparisons among the heterogeneous body of literature by categorising papers into one of three groups based on type of nature interaction: accessibility, exposure and engagement.

- The study highlights the need for more rigorous tools to measure nature interactions.

- Additionally, it highlights the growth of research focusing on child populations in the last 5 years.

- This study concludes that although the findings vary based on mental health outcome and type of nature interaction, it can be argued that nature does have a beneficial influence on children's and teenagers' mental health. 
inconsistent and often non-significant, demonstrate the need for more in depth and rigorous research. Creating a more standardised measure for operationalising nature is necessary to make these findings generalisable. Understanding why there are differences in the findings is critical to establishing evidencebased recommendations for policy makers and planners in designing neighbourhoods and cities. This review identified the importance in promoting nature interactions to children and teenagers in supporting their mental health.

Acknowledgements We would like to thank the Expert Advisory Panel and Systematic Review Team for their guidance and assistance in the completion of this systematic review.

Contributors JG devised and supervised the project. All authors made substantial contributions to study design, including development of systematic review procedures. ST and DT conducted the literature search and data extraction and independently assessed the methodological quality of included studies and conducted analysis. JG adjudicated in any disagreements in methodological quality assessments and contributed to analysis. ST, DT and JG drafted the original manuscript and WA critically reviewed the manuscript for important intellectual content. All authors have given approval of this final version to be published and agree to be accountable for all aspects of the work. No others fulfil the criteria for authorship.

Funding This systematic review was made possible through funding from The Lawson Foundation. ST and DT received trainee support from the Children's Health Research Institute through funding from the Children's Health Foundation.

Disclaimer The funders were not involved in the design or completion of the review

\section{Competing interests None declared.}

Patient consent Not required

Provenance and peer review Not commissioned; externally peer reviewed.

Open access This is an open access article distributed in accordance with the Creative Commons Attribution Non Commercial (CC BY-NC 4.0) license, which permits others to distribute, remix, adapt, build upon this work non-commercially, and license their derivative works on different terms, provided the original work is properly cited, appropriate credit is given, any changes made indicated, and the use is non-commercial. See:http://creativecommons.org/licenses/by-nc/4.0/.

(c) Article author(s) (or their employer(s) unless otherwise stated in the text of the article) 2018. All rights reserved. No commercial use is permitted unless otherwise expressly granted.

\section{REFERENCES}

1 Waddell C, Hua JM, Garland OM, et al. Preventing mental disorders in children: a systematic review to inform policy-making. Can J Public Health 2007;98:166-73.

2 World Health Organization. Mental health: strengthening our response. Geneva: World Health Organization, 2016.

3 Avison WR. Incorporating children's lives into a life course perspective on stress and mental health. J Health Soc Behav 2010;51:361-75.

4 Maller C, Townsend M. Children's mental health and wellbeing and hands-on contact with nature. Int J Learn 2006;12:359-72.

5 Mantler A, Logan AC. Natural environments and mental health. Adv Integr Med 2015;2:5-12

6 Reed K, Wood C, Barton J, et al. A repeated measures experiment of green exercise to improve self-esteem in UK school children. PLoS One 2013;8:e69176.

7 Ritchie SD, Wabano MJ, Russell K, et al. Promoting resilience and wellbeing through an outdoor intervention designed for Aboriginal adolescents. Rural Remote Health 2014; 14:2523

8 Bardone AM, Moffitt TE, Caspi A, et al. Adult mental health and social outcomes of adolescent girls with depression and conduct disorder. Dev Psychopathol 1996:8:811-29

9 Eaton WW, Martins SS, Nestadt G, et al. The burden of mental disorders. Epidemiol Rev 2008:30:1-14.

10 Annerstedt M, Währborg P. Nature-assisted therapy: systematic review of controlled and observational studies. Scand J Public Health 2011:39:371-88.

11 Clark C, Myron R, Stansfeld S, et al. A systematic review of the evidence on the effect of the built and physical environment on mental health. J Public Ment Health 2007:6:14-27.

12 Gascon M, Triguero-Mas M, Martínez D, et al. Mental health benefits of long-term exposure to residential green and blue spaces: a systematic review. Int I Environ Res Public Health 2015;12:4354-79.
13 Ack L, Maheswaran R. The health benefits of urban green spaces: A review of the evidence.J Public Health 2011:33:212-22.

14 Thompson Coon J, Boddy K, Stein K, et al. Does participating in physical activity in outdoor natural environments have a greater effect on physical and mental wellbeing than physical activity indoors? A systematic review. Environ Sci Technol 2011:45:1761-72.

15 Lehti V, Niemelä S, Hoven C, et al. Mental health, substance use and suicidal behaviour among young indigenous people in the Arctic: a systematic review. Soc Sci Med 2009;69:1194-203.

16 Audrey S, Batista-Ferrer $\mathrm{H}$. Healthy urban environments for children and young people: A systematic review of intervention studies. Health Place 2015;36:97-117.

17 Brussoni M, Gibbons R, Gray C, et al. What is the Relationship between Risky Outdoor Play and Health in Children? A Systematic Review. Int J Environ Res Public Health 2015;12:6423-54.

18 Christian H, Zubrick SR, Foster S, et al. The influence of the neighborhood physical environment on early child health and development: A review and call for research. Health Place 2015:33:25-36.

19 Petticrew M, Roberts H. Systematic Reviews in the Social Sciences: A Practical Guide Oxford: Blackwell Publishing, 2006

20 Balseviciene B, Sinkariova L, Grazuleviciene R, et al. Impact of residential greenness on preschool children's emotional and behavioral problems. Int J Environ Res Public Health 2014:11:6757-70.

21 Whittington A, Aspelmeier JE, Budbill NW. Promoting resiliency in adolescent girls through adventure programming. Journal of Adventure Education and Outdoor Learning 2016;16:2-15.

22 Markevych I, Schoierer J, Hartig T, et al. Exploring pathways linking greenspace to health: Theoretical and methodological guidance. Environ Res 2017;158:301-17.

23 Dzhambov A, Hartig T, Markevych I, et al. Urban residential greenspace and mental health in youth: Different approaches to testing multiple pathways yield different conclusions. Environ Res 2018;160:47-59.

24 Triguero-Mas M, Donaire-Gonzalez D, Seto E, et al. Natural outdoor environments and mental health: Stress as a possible mechanism. Environ Res 2017:159:629-38

25 Amoly E, Dadvand P, Forns J, et al. Green and blue spaces and behavioral development in Barcelona schoolchildren: the BREATHE project. Environ Health Perspect 2014;122:1351-8.

26 Barton J, Sandercock G, Pretty J, et al. The effect of playground- and nature-based playtime interventions on physical activity and self-esteem in UK school children. Int J Environ Health Res 2015:25:196-206.

27 Bowen DJ, Neill JT. Effects of the PCYC Catalyst outdoor adventure intervention program on youths' life skills, mental health, and delinquent behaviour. Int J Adolesc Youth 2016;21:34-55.

28 Bowen DJ, Neill JT, Crisp SJR. Wilderness adventure therapy effects on the mental health of youth participants. Eval Program Plann 2016;58:49-59.

29 Cammack C, Waliczek TM, Zajicek JM. The Green Brigade: The psychological effects of a community-based horticultural program on the self-development characteristics of juvenile offenders. Horttechnology 2002;12:82-6.

30 Clark JP, Marmol LM, Cooley R, et al. The Effects of Wilderness Therapy on the Clinical Concerns (on Axes I, II, and IV) of Troubled Adolescents. Journal of Experiential Education 2004:27:213-32.

31 Feda DM, Seelbinder A, Baek S, et al. Neighbourhood parks and reduction in stress among adolescents: Results from Buffalo, New York. Indoor Built Environment 2015;24:631-9.

32 Flouri $\mathrm{E}$, Midouhas $\mathrm{E}$, Joshi $\mathrm{H}$. The role of urban neighbourhood green space in children's emotional and behavioural resilience. J Environ Psychol 2014;40:179-86.

33 Greenwood A, Gatersleben B. Let's go outside! Environmental restoration amongst adolescents and the impact of friends and phones. J Environ Psychol 2016:48:131-9.

34 Gubbels JS, Kremers SP, Droomers M, et al. The impact of greenery on physical activity and mental health of adolescent and adult residents of deprived neighborhoods: A longitudinal study. Health Place 2016;40:153-60.

35 Harper NJ, Russell KC, Cooley R, et al. Catherine Freer Wilderness Therapy Expeditions: An Exploratory Case Study of Adolescent Wilderness Therapy, Family Functioning, and the Maintenance of Change. Child and Youth Care Forum 2007:36:111-29.

36 Hinds J. Woodland Adventure for Marginalized Adolescents: Environmental Attitudes, Identity and Competence. Applied Environmental Education \& Communication 2011;10:228-37

37 Huynh Q, Craig W, Janssen I, et al. Exposure to public natural space as a protective factor for emotional well-being among young people in Canada. BMC Public Health 2013:13:1-14

38 Kelz C, Evans GW, Röderer K. The Restorative Effects of Redesigning the Schoolyard: A Multi-Methodological, Quasi-Experimental Study in Rural Austrian Middle Schools. Environ Behav 2015;47:119-39.

39 Kim JH, Lee C, Sohn W. Urban Natural Environments, Obesity, and Health-Related Quality of Life among Hispanic Children Living in Inner-City Neighborhoods. Int J Environ Res Public Health 2016;13:121-15.

$40 \mathrm{Kuo} \mathrm{FE}$, Taylor AF. A potential natural treatment for attention-deficit/hyperactivity disorder: evidence from a national study. Am J Public Health 2004;94:1580-6. 
41 Markevych I, Tiesler CM, Fuertes E, et al. Access to urban green spaces and behavioural problems in children: Results from the GINIplus and LISAplus studies. Environ Int 2014;71:29-35.

42 McCracken DS, Allen DA, Gow AJ. Associations between urban greenspace and health-related quality of life in children. Prev Med Rep 2016;3:211-21.

43 Mutz M, Müller J. Mental health benefits of outdoor adventures: Results from two pilot studies. J Adolesc 2016;49:105-14.

44 Opper B, Maree JG, Fletcher L, et al. Efficacy of outdoor adventure education in developing emotional intelligence during adolescence. Journal of Psychology in Africa 2014;24:193-6.

45 Roe J, Aspinall P. The restorative outcomes of forest school and conventional school in young people with good and poor behaviour. Urban For Urban Green 2011;10:205-12.

46 Romi S, Kohan E. Wilderness Programs: Principles, Possibilities and Opportunities for Intervention with Dropout Adolescents. Child Youth Care Forum 2004:33:115-36.

47 Söderström M, Boldemann C, Sahlin U, et al. The quality of the outdoor environment influences childrens health -- A cross-sectional study of preschools. Acta Paediatr 2013;102:83-91.
48 Taylor AF, Kuo FE. Children with attention deficits concentrate better after walk in the park. J Atten Disord 2009;12:402-9.

49 Faber Taylor A, Kuo FEM. Could Exposure to Everyday Green Spaces Help Treat ADHD? Evidence from Children's Play Settings. Appl Psychol 2011;3:281-303.

50 Taylor AF, Kuo FE, Sullivan WC. Coping with ADD. The Surprising Connection to Green Play Settings. Environ Behav 2001;33:54-77.

51 van den Berg $A E$, van den Berg CG. A comparison of children with ADHD in a natural and built setting. Child Care Health Dev 2011;37:430-9.

52 van Lier LE, Utter J, Denny S, et al. Home Gardening and the Health and Well-Being of Adolescents. Health Promot Pract 2016;18:34-43.

53 Ward JS, Duncan JS, Jarden A, et al. The impact of children's exposure to greenspace on physical activity, cognitive development, emotional wellbeing, and ability to appraise risk. Health Place 2016;40:44-50.

54 Wells NM, Evans GW. Nearby Nature: A Buffer of Life Stress among Rural Children. Environ Behav 2003:35:311-30.

55 Wood C, Gladwell V, Barton J. A repeated measures experiment of school playing environment to increase physical activity and enhance self-esteem in UK school children. PLoS One 2014;9:e108701. 